\title{
Memórias de uma normalista: entrevista com Beatriz Daudt Fischer
}

\author{
Memories of a normalist: \\ interview with Beatriz Daudt Fischer \\ Memorias de una normalista: \\ entrevista con Beatriz Daudt Fischer \\ Diogo FRANCO RiOS $\oplus^{1}$ \\ Maria Cecilia Bueno Fischer (1) ${ }^{2}$ \\ ${ }^{1}$ Universidade Federal de Pelotas, Pelotas, RS, Brasil. \\ ${ }^{2}$ Universidade Federal do Rio Grande do Sul, Porto Alegre, RS, Brasil.
}

\begin{abstract}
Apresentamos para o leitor a textualização de trechos de uma entrevista realizada com Beatriz Terezinha Daudt Fischer, sobre as suas memórias da Escola Normal Santa Catarina, em Novo Hamburgo, Rio Grande do Sul, onde frequentou o Curso Normal de 1964 a 1967. Os trechos que trazemos aqui tratam, mais especificamente, sobre a matemática presente no Curso e no estágio realizado pela entrevistada, enquanto normalista, em uma turma de $1^{\circ}$ ano Primário no Ginásio São
\end{abstract} Luiz, naquela mesma cidade.

A entrevista foi realizada por Diogo Franco Rios e Maria Cecilia Bueno Fischer ${ }^{1}$, em Porto Alegre, no dia 14 de setembro de 2018, na casa da entrevistada, e pretendeu produzir um registro das memórias da ex-normalista sobre a matemática na sua formação. Os cadernos de estágio dela já têm possibilitado algumas análises historiográficas² no âmbito do Projeto "Estudar para ensinar: práticas e saberes matemáticos nas escolas normais do Rio Grande do Sul (1889-1970)", realizado com financiamento da Chamada Universal do CNPq - 2016, em parceria da Universidade Federal do Rio Grande do Sul (UFRGS) e da Universidade Federal de Pelotas (UFPel).

A entrevistada, Beatriz Terezinha Daudt Fischer, é pesquisadora de História da Educação, aposentada depois de uma longa trajetória como pesquisadora na UFRGS e na Universidade do Vale do Rio dos Sinos (UNISINOS). Durante sua carreira, ocupou-se com a formação de professores, atuando principalmente nos cursos de Pedagogia e demais Licenciaturas (UFRGS e UNISINOS) e no Programa de Pós-Graduação em Educação (UNISINOS).

Entre as suas produções, destacamos o livro Professoras: histórias e discursos de um passado presente, decorrente de sua tese de doutorado, que teve como foco professoras primárias gaúchas, formadas nas instituições formadoras então denominadas Escolas Normais, e que atuaram no magistério nas décadas de 1950 e 1960.

Dito isso, convidamos à leitura da entrevista, destacando que as memórias de Beatriz a respeito do tema da entrevista compõem-se em diálogo com sua trajetória profissional posterior à conclusão do Curso Normal, como pesquisadora e docente no Ensino Superior.

\footnotetext{
Registramos um agradecimento ao licenciando em matemática, à época, Leonardo Thomaz Sauter, que colaborou na primeira etapa de transcrição da entrevista.

2 Beatriz nos cedeu os cadernos do período do estágio, cuja análise já resultou na produção de dois artigos, publicados recentemente e com acesso online Disponíveis em: histemat.com.br/index.php/HISTEMAT/article/download/139/95. Acesso em: 16 jun. 2019; e sbemrs.org/revista/index.php/2011_1/article/ view/410. Acesso em: 16 jun. 2019.
} 
จ BEATRIZ DAUDT FISCHER (BDF): Então, Escola Normal... Existia um colégio de freiras do Primário, Ginásio e a Escola Normal eram em um outro colégio, mas da mesma linha, mesma congregação de freiras, Escola Santa Catarina.

\section{MARIA CECILIA BUENO FISCHER (MCBF): O Pri- mário era o São Luiz?}

จ BDF: São Luiz. Mas as freiras eram da congregação Santa Catarina. E aí, já para ir para o Ginásio tinha que fazer o tal de Exame de Admissão ao Ginásio. Eu tenho um livro "Admissão ao Ginásio". Na verdade, se dizia assim na época: que do primeiro ao quarto ano Primário ia trabalhando conteúdos, no quinto seria uma espécie de revisão. Bom, o quinto [ano] seria, assim, uma admissão ao Ginásio, só que para ir para o Ginásio - no nosso caso, outro prédio, outra escola, da mesma linha, mas outra escola - tinha que fazer o Exame de Admissão. Então, daí sim, tinha português, matemática, depois quero mostrar para vocês... porque isso foi se consolidando, eu acho, na minha formação. Quer dizer, estudei matemática no Primário, estudei matemática no Ginásio e isso eu devo ter levado para a Escola Normal.

\section{MCBF: Nessa mesma Escola?}

- BDF: Na outra Escola. No Santa Catarina. O Ginásio era lá. E aí tinha um vestibular para a Escola Normal. Assim como tinha o [Exame de] Admissão do Primário para o Ginásio, a gente fazia... eles chamavam de vestibular, imagina! A gente se preparava, tinha português, matemática, basicamente, e eu acho que conhecimentos gerais. Mas, português e matemática eram importantes. Isso para entrar para o primeiro normal, segundo normal, terceiro normal e, depois, estágio.

Eu não tive, na Escola Normal, eu acho que eu não tive a disciplina de matemática, eu tive didática. Então, eu não sei se na época se confiava nessa formação anterior, que realmente sempre teve matemática, português, sempre teve. Só que ali no Ensino Médio, na Escola Normal, eu tinha filosofia, sociologia, português - muito bom o português, até hoje sei que aprendi muita gramática, literatura, na Escola Normal, estudando literatura portuguesa, um pouco, e literatura brasileira e fazíamos análise literária. O Normal foi um curso... eu hoje acho que, naquela época, o Curso Normal equivaleria hoje a um curso superior, de tão bom que era! Mas não me lembro de nenhuma disciplina de matemática, eu até quero ver mais isso...

$\mathrm{Eu}$ estive lá no Colégio [Santa Catarina], elas me deixaram ver o livro, na verdade, o único livro que elas conseguiram é o livro de atas para diplomação, depois eu vou mostrar para vocês. Está lá, mas não vi nada de matemática. Então, isso eu acho interessante, porque que insistiram tanto em português, literatura... eu gostava muito, gostava muito de filosofia, sociologia eu amava! Foi muito bom meu Curso Normal. Terminado dezembro, no terceiro ano, elas faziam o sorteio dos estágios, a gente podia pegar qualquer turma das escolas [em] que elas tinham estágio: o próprio São Luiz, um coleguinho que as freiras tinham do lado do Colégio, que era para criança pobre, do lado do Colégio Santa Catarina, e a Escola Madre Regina, que era sempre atendida por estagiárias.

Tinha uma ou outra escola pública para estagiar, mas eu acho que a maioria era de escolas privadas que as freiras tinham acesso, onde era nosso estágio. Só que a nossa turma era uma turma muito grande e, pela primeira vez na história do Colégio, ia ter que ter estágio nos dois semestres. Ou seja, em vez de nos formarmos em julho, já que o estágio era sempre de um semestre, nós nos formaríamos só no fim do ano, porque primeiro ia metade da turma estagiar, e depois a outra metade. Então com isso, o que é que aconteceu? $\mathrm{Eu}$, claro, fui sorteada para o segundo semestre. $\mathrm{Eu}$ ia ficar fazendo o quê? Como na época a prefeitura aceitava e precisava de professores municipais, sem concurso, sem nada, eu e outras colegas fomos na prefeitura... faltavam professores... Mas, aí ficaram loucos, porque tinha várias professoras leigas, que mal tinham o Ginásio, e nós já estávamos terminando a Escola Normal. Aí, várias colegas e eu, nós pegamos... então eu comecei a trabalhar na prefeitura, em março, sem ainda ter feito o estágio, que eu fiz de agosto em diante, no São Luiz. Eu fiz o estágio no segundo semestre, mas a minha experiência começa em março em uma escola de periferia.

\section{MCBF: Quando tu estavas fazendo estágio, tu conti- nuaste nessa escola?}

- BDF: Sim, na Escola Municipal Caldas Júnior, na Santo Afonso, onde tinha enchente do Rio dos Sinos, meus alunos eram muito pobres. Mas a diretora sabia que eu ia ter estágio, gostou do meu trabalho e disse: "vamos tentar te colocar em um turno [de modo] que tu possas continuar o estágio". Então, continuei na Escola Municipal e, à tarde, fazia o estágio no São Luiz, que era escola das freiras, no centro da cidade, perto da minha casa. Minha mãe fazia tudo para mim! Eu só me dedicava para planejar aquelas aulas, eram duas turmas de primeiro ano, mas nada a ver uma com a outra. Uma, [era a das] crianças de classe média ou alta, no São Luiz, e a outra, aquela pobreza lá, enfim. Eu só dormia em casa, almoçava correndo, e a mãe fazia tudo para mim. Sou quase filha única, tá, tem 
que entender isso, meu irmão é quase oito anos mais velho que eu, casou cedo e então eu fiquei de... mas, assim, por que que eu estou dizendo isso? Porque acho que a Escola Normal que nós fizemos, a nossa turma, foi bem sólida em termos de preparação, tanto que as minhas colegas - ano passado fizemos cinquenta anos de formatura do magistério -, quando a gente conversa, a maioria ficou [sendo] diretora ou coordenadora, na prefeitura. Era um grupo que tinha muita liderança.

A gente gostava de estudar, fazia muita bagunça também, mas curtia essa coisa de querer ser professora, então eu acho que eu fui assim, sei lá se vou dizer... privilegiada, foi um curso muito bom. E uma outra coisa que eu me lembro, que tu já me perguntaste, quando tinha uma turma para dar aula, no caso do estágio ou alguma coisa assim, quem é que orientava? $\mathrm{Na}$ verdade, não tinha muita orientação. Tinha visitas, tinha colegas que tremiam quando chegavam as freiras ou as professoras leigas, que eram as chamadas equipes de supervisão. Eu confesso que não tinha muito medo delas, porque sempre fui boa aluna - eu e uma outra colega tiramos o primeiro lugar no estágio, vamos dizer assim. Elas gostavam das aulas, tanto que uma freira disse para uma outra e eu fiquei sabendo: "eu gostaria de ser aluna da Beatriz". Claro, eu fazia... fiz o Nilton, meu namorado à época, levar uma árvore para dentro da sala de aula, porque eu gostava e curtia e sempre fui muito criativa, então foi um tempo muito bom. Mas acho que é meu jeito meio... eu fui uma aluna muito religiosa, eu era presidente do apostolado da oração ${ }^{3}$, coordenava várias coisas, presidente do grêmio estudantil, presidente do orfeão, quer dizer, estava sempre metida. Orfeão Vila Lobos era o coral. Muito metida e, ao mesmo tempo, um pouco, assim, missionária.

Tinha reunião uma vez por mês, tinha reunião das estagiárias, e eu vi o que é que a equipe tinha anotado, elas não nomeavam ninguém, mas a gente ficava sabendo que algumas gurias, colegas, estavam sendo muito... uma se reprovou, inclusive. Mas, eu acho que não, ninguém orientava assim: "pega esse conteúdo de matemática, faz isso, faz aquilo". Tanto que quando terminou tudo, que eu quis continuar estudando, eu fui ao Colégio perguntar para as freiras - imagina como eu era ligada a elas -o que é que eu podia estudar. Aí, uma das freiras disse: "tu tens que fazer filosofia". Eu digo, "pelo amor de Deus" - eu disse para ela -,"o que é que eu vou fazer com a filosofia? Disse a freira: "ué,

\footnotetext{
Segundo a entrevistada, trata-se de uma organização da Igreja Católica que, na época, reunia alunas do Curso Ginasial e do Curso Normal com o objetivo de reverenciar o Sagrado Coração de Jesus através de orações e, principalmente, através da missa e comunhão na primeira sexta-feira de cada mês.
}

vai dar aula de filosofia, fazer pesquisa". "Não, não, eu quero trabalhar nisso que vocês trabalham. Eu quero... qual é o curso? Eu quero ser orientadora de estágio”.

Eu achei que houve muita injustiça. Por isso que eu digo que eu era missionária, porque eu via colegas indo mal no estágio, mas sem orientação, entende? A gente é que às vezes dizia: "não faz isso, faz aquilo". As gurias ficavam meio perdidas. E eu pensei: eu quero trabalhar nisso. Quero trabalhar na Escola Normal. Daí ela me disse: "faz Pedagogia". E nem sabia o que é que eram os cursos, a gente não tinha ideia. Ela disse: "é, faz Pedagogia, foi o que eu fiz". Eu acho que ela era recém-formada, ela era nova. E daí foi toda essa história. E da minha turma, só uma fez Pedagogia, as outras foram para a História, Ciências Sociais, né?! E a maioria não seguiu adiante. Mas eu, eu quero dizer que no estágio não tinha essa coisa de "olha, o programa de ensino é esse".

No Colégio, e isso vale para Escola Municipal também, tinha reunião e aí diziam: "olha, o primeiro ano vai trabalhar mais ou menos isso e isso". Mas não era uma coisa assim, tu está trabalhando isso, não tinha esse controle, eu acho que hoje deve ter mais controle, né?!

A Secretaria de Educação e Cultura, na época, por isso que [a sigla] era SEC, era através de inspetoras, então a inspetora era alguém que recebia uma delegação de ir às escolas privadas para verificar o andamento dos trabalhos. Eu acho que até hoje deve ter alguma coisa assim. Mas naquele tempo era assim: a gente sempre sabia, no caso da professora de Sociologia, por exemplo, eu sabia que [ela] também era inspetora, e às vezes a professora dizia: "olha, hoje chegou a fulana, que veio da SEC". Então, havia um certo controle. E aí, a gente também ficou sabendo que a Secretaria de Educação tinha uns programas de ensino. Tu abrias ele assim [o programa], e ali estava o primeiro ano, o segundo ano, o terceiro..., isso tinha para cada disciplina. E a gente mais ou menos seguia ali.

No meu caso, no primeiro ano, eu tinha que dar a noção de dúzia, meia dúzia, eu tinha que ensinar os números - se diz números ou numerais? - até cem, um começo da soma e da subtração. Isso era do primeiro ano. Mas isso assim, estava ali naquele programa, eu não me lembro bem.

$\mathrm{Eu}$ acho que muita coisa eu ia assim, perguntando. Perguntava no Colégio onde fazia estágio, perguntava para as professoras. Tinha, eventualmente, reuniões. E na Escola Municipal tinha sempre colegas de mais experiência, algumas com menos estudo que a gente, porque na Escola Municipal bastava às vezes ter [cursado o] Ginásio para dar aula, naquele tempo. Mas elas tinham uma experiência incrível, então de vez em 
quando eu perguntava. Eu, às vezes, fico pensando que eu acho que eu aprendi mais na prática em três anos na Escola Municipal, com aquelas crianças tão difíceis, do que no meu Curso Normal, entende.

Eu penso que a maior formação da Escola Normal foi uma formação moral, não moralista, tinha também os momentos de moralismo, mas era uma coisa muito do gosto por ensinar, da vocação, se falava muito em vocação, as aulas de Filosofia e Sociologia, tinha muito... era uma coisa mais de formação. Não se falava em cidadão, mais uma formação humana do que técnica, propriamente.

As aulas de didática eram todas ditadas, todas! Mas eram aulas ditadas, então era assim, ela falava e depois a gente passava a limpo. Ela ditava como fazer, a gente tinha que organizar grandes álbuns, isso eu me lembro, e aí fazia... Mas eu tenho assim... como é que tu vais trabalhar determinadas coisas, estava naquele álbum, entende?! Daí tu apresentavas para ela e tal. Não sei se a minha avaliação é correta, mas eu acho que a parte de didática mesmo, como dar aula, como ensinar, eu aprendi muito mais nos meus três anos de prática pedagógica na Escola Municipal. Mais [do] que no estágio. Porque peguei uma época que tinha uma orientação muito boa da prefeitura, tinha uma equipe. $\mathrm{E}$ aí faziam reuniões muito seguidamente, reuniam uma coisa que elas chamavam de "núcleos": três escolas municipais se reuniam em uma. Isso era, mais ou menos, de dois em dois meses. E ali eu cresci muito, naquele período de três anos tinha, todos os meses de julho teve seminários, uma semana de formação. Então... claro que a Escola Normal tem toda uma bagagem, eu não nego isso, mas a prática me deu bem outra, aprendi muito com as colegas também.

$\mathrm{Eu}$ fui... em 64 eu fiz o primeiro ano Normal, bem com o golpe militar ali, 64, 65, 66, e em $67 \mathrm{fiz}$ o estágio. Quando eu fiz o estágio, eu já estava na Escola Municipal. Então, em 67, 68 e 69 eu estava na Escola Municipal; só que em 68 já estava na faculdade. Primeiro ano da Pedagogia, eu tive também muita sorte de pegar um grupo [de colegas] muito bom, mas isso é toda uma outra história que se atravessa...

Mas por que que eu estou falando isso? Porque esses anos que eu estava começando ali no... principalmente em 68, 69, que eu estava na Escola Municipal, como eu fazia Pedagogia em São Leopoldo, o professor de Sociologia me convidou, [perguntou] se eu não queria trabalhar no que se chamava, em São Leopoldo, no Colégio São José, de Escola Normal de Férias. O que é que era isso? Foi maravilhoso! Em julho e janeiro, as professoras do interior, que não tinham Escola Normal, vinham fazer o curso de formação intensivo. Por exemplo, em julho a gente trabalhava quatro semanas, manhã e tarde. Então elas fizeram o Curso Normal nas férias, em três anos de férias. Eram alunas (em maioria, mulheres) que já atuavam como professoras no interior, tudo gente que trabalhava na periferia.

Aí, a gente dava aulas maravilhosas. Eu comecei a me encantar por isso e aí, depois de três anos dando aula regular no município, veio o convite para eu trabalhar na Escola Normal privada, de São Leopoldo. Aí eu larguei tudo. Eu, simplesmente, larguei e fui dar aula na Escola Normal, larguei o município que era... claro que aqueles três anos constaram na minha trajetória para me aposentar, porque eu tinha comprovante, tudo. Mas eu queria, meu sonho era trabalhar na Escola Normal. Aí me convidaram, larguei o município!

Hoje eu fico pensando: puxa, mas eu estava num sistema público municipal que, querendo ou não, pagava direitinho e tal. Dois anos depois, a gente foi para rua da Escola [Normal]. Eu sei que foi maravilhoso, mas dois anos depois estava tudo [todos] na rua e as freiras não me colocaram. Nós voltamos de uma viagem em fevereiro, de férias, e as freiras nos chamaram, estava todo mundo demitido e eu não fui demitida e eu esperei que me chamassem e não. Aí eu - tu vês o que se faz com essa idade, né?! - eu fui lá e perguntei, eu me dava muito com uma freira, aí eu fui e disse: "Irmã, eu queria saber o seguinte, todo mundo foi chamado e demitido". E eles diziam: "é, tivemos que demitir, mudou a direção, né?". A outra freira era bem de esquerda e essa não, daí ela disse: "Não, é que mudou a direção, tinha muitas denúncias do que vocês faziam na Escola, está tomando outra dimensão”. E eu disse: "mas por que eu ainda não fui demitida?" [risos] eu estava indignada! Não, eu não conseguia nem dormir. Como é todo mundo está sem... Todo mundo desempregado... Aí a freira, essa que era minha amiga, disse: "Beatriz eu vou te ser bem sincera, porque eu sou tua amiga. A irmã diretora está um pouco com receio da turma que está indo para o estágio, porque eram gurias ótimas, alguém tem que "segurar" essas gurias. Elas acham que tu ficando...". Entendeu? Quer dizer, eu ia ser tipo uma bucha de canhão... não que as gurias fossem se revoltar porque eu fui demitida, não. Acho que não ia chegar a isso.

Imagina, isso era 71 já. Ia iniciar 71. A freira falou: "tu ficas, tu nos ajudas, tu continuas com o terceiro ano e a gente pensou em tu trabalhares no estágio". Entende? Eu devia ser meio mediadora, alguma coisa assim. Eu digo, “ah, tá!” Eu fiz de conta. E daí eu vim para casa, eu falei com Nilton, "eu vou me demitir". Aí fiquei desempregada uns três ou quatro meses, depois apareceu uma chance de trabalhar na Delegacia de Ensino. 
Mas por que que eu estou falando tudo isso? Porque eu acho que essa vontade de trabalhar na formação de professores ela sempre foi permanente. Quando eu fui lá perguntar para a freira, que faculdade eu faço para trabalhar nisso, ela disse "Pedagogia", já estava um pouco com essa ideia [de] que eu queria trabalhar com formação de professores. E o que é que eu queria trabalhar? Era mais essas disciplinas, mais, eu diria, da área das humanas, era disso que eu gostava, então, eu nunca fui voltada para a coisa da Matemática. Por que é que eu volto? Porque é o que interessa mais a vocês. Eu penso, assim, quando eu trabalhava com meus alunos de anos iniciais, trabalhava bem com matemática também, até porque era básica, né? Mas não era uma coisa assim que aí, hoje eu vou... não era, matemática nunca foi meu forte!

Comecei o Curso de Pedagogia e a Léa Fagundes era a pessoa que ia introduzir Piaget e Matemática Moderna. Era ali, isso era 1968, 69. E a Léa, nunca vou esquecer... eu era professora lá em Novo Hamburgo e já estava ali na Faculdade. E a Léa, que a gente não conhecia, formou grupos - era uma época de muitos trabalhos em grupos em todo Curso de Pedagogia, e a Léa formou grupos e trouxe os blocos lógicos, não disse nome, não disse nada, muito didática ela. Ela botou no meio de cada grupo e disse: "vocês brinquem, façam o que vocês quiserem". Nós fomos explorando aquilo, depois ela ia construindo conosco ali os conceitos. Eu achei maravilhoso isso. E isso eu quis introduzir um pouquinho, ainda sem os blocos lógicos lá em Novo Hamburgo, alguma coisa assim, né?!

Porque eu acompanhava, de ouvir falar, que no Colégio São Luiz, já não estava mais fazendo estágio, lá tinha um grupo que trabalhava Matemática reformulada. Enfim, tinha um grupo que fazia cursos com a Esther Grossi, aqui [no Rio Grande do Sul] estava se formando o GEEMPA, e levava para a escola particular, mas ali na Escola Municipal eu tentei algumas coisas, no concreto... Isso para mim, de aparecer a ideia do concreto para o abstrato, eu não aprendi na Escola Normal, eu aprendi mais no Curso de Pedagogia. Interessante isso, né? Porque eu acho que eu fui consolidando mais a minha formação, até mais de alguns conceitos, no Curso de Pedagogia. Não sei. E depois, na medida em que eu fiz o Curso de Pedagogia, eu não trabalhei mais com criança. Então eu fui trabalhando na Escola Normal São José, depois a gente foi passar um período em Stanford, ficamos três anos lá.

O que é que eu vou pensar assim... de que tipo de saldo, no sentido da minha formação. Eu me dei conta disso. Que a Escola Normal não foi tão preocupada com questões específicas de conteúdo de Matemática. E eu acho que tinha que ser.
Quando eu fiz Escola Normal, eu não pensava em fazer faculdade, mas terminei e queria fazer faculdade. E uma coisa puxou a outra. E muito por causa do Nilton, até ontem eu estava comentando com a minha mãe. Que muita experiência eu não teria tido se não fosse o Nilton, que ele me puxava, entende? E, foi muito assim, uma provocação de sempre estudar.

\section{MCBF: Tu disseste que não usavam livros? Como que é?}

○ BDF: Não, eu não me lembro, assim de matemática ou de história, não. Era tudo assim, elas davam aula e a gente passava a limpo os pontos, mas não tinha nada de matemática, não. Eu achei interessante isso: professora, como é que era a formação? O Curso de Formação de Professores Primários era o FPP [Formação de Professores Primários], aí depois a Lei de Diretrizes e Bases e tal, e aí aqui dava um pouco a estrutura, elas ensinavam para nós coisas sobre a estrutura escolar, entende?! Então os cadernos... era muito isso, assim, de passar a limpo os pontos.

De matemática eu não tenho nada. O que eu tenho mais do meu Ginásio aqui [em casa], talvez vocês encontrem coisas que possa interessar, e esse aqui do Primário, eu achei um livro de matemática: "Brincando com Números". Vamos ver o ano... [olhando no livro] é o ano 57 e então, dêem uma olhada nisso [depois].

○ BDF: O que mais tu queres saber?

DIOGO FRANCO RIOS (DFR): Bom, a primeira coisa era isso, falar sobre a Escola, tuas memórias da Escola. Mas, a gente queria saber mais do estágio.

จ BDF: É, posso falar mais. Então, eu, na verdade no sorteio, eu tinha ficado numa escola lá de Hamburgo Velho, das freiras, essa que eu te falei. Para mim era muito mais difícil e uma colega quis trocar. Então, eu troquei para o Colégio São Luiz, que era bem perto da minha casa, eu morava ali do lado, e aí foi bom. Só que... eu pensava assim, tá, eu vou pegar, peguei o trabalho no município e isso vai me dar uma boa cancha, foi muito bom, né?! E eu vou, assim, quando chegar mais perto de agosto, que ia começar o meu estágio, eu vou visitar a minha colega... porque uma colega estava com essa turma no primeiro semestre do ano. Eu ia pegar uma turma de alfabetização, então eu fiz duas visitas para essa minha colega que, casualmente, e ainda bem, era uma colega boa. Boa professora, ela sempre tinha sido estudiosa e tal, então, ela preparou bastante os alunos que estavam quase... alguns já quase lendo, assim, no final do primeiro semestre. Não me lembro se ela disse para a turma que eu ia ser a professora, isso eu não me lembro. Eu sei que quando começou em agosto, acho que foi a 
freira, alguém levou e me apresentou para a turma, e era uma turma de crianças... só meninas, colégio feminino.

Era uma turma bem boa e estava bem, vamos dizer assim, dentro de um nível bom para segundo semestre. Tinha algumas alunas com dificuldade, como sempre tem, mas era uma turma boa. Então, eu fiquei feliz. Eu não me lembro agora de quantos eram, mas era uma turma grande, a sala de aula era muito boa e eu me lembro que num dos cadernos, não sei se num desses que eu dei, que eu fiz lá o versinho: "Aprendi na minha escola”, que é a Escola [em] que eu estudei, do primeiro ao quinto, do pré ao quinto ano. É, eu coloquei, acho que está em um caderno: "Aprendi na minha escola a ler, escrever e contar e agora, na mesma sala, sou eu que vou ensinar". Era um versinho lá que eu bolei. E, realmente, era uma sala de aula em que eu tinha estudado, né?! Foi muito bonito. E... as atividades, eu preparava com muita vontade, eu sabia que eu, eventualmente, seria observada. Às vezes passavam duas semanas, não vinha ninguém. E, eventualmente, numa semana podia vir mais de uma supervisora de estágio. Era sempre surpresa, não sabia quem vinha visitar.

\section{MCBF: Não sabia quem é que vinha?}

○ DF: É. Era uma da equipe de estágio, que supervisionava o estágio. E eram essas também que faziam reunião uma vez por mês, com as estagiárias que estavam em ação. E uma coisa que eu lembro também, acho que era o mês de outubro, tinha uma menina que era muito, era meio precoce, assim. Era uma família muito grande, e essa aluninha, 7 anos, era uma das pequenas, assim muito esperta. No dia dos professores, parece que eu estou vendo, eu, depois do recreio, ia entrar na aula, não sabia que a turma já estava lá dentro, e ela não me deixou entrar. Essa menina, sete anos, não lembro o nome dela, ela organizou, escreveram um quadro, fizeram uma homenagem para o dia do professor. Imagina, primeiro ano, mas essa guria era muito dinâmica. Isso eu me lembro bem, foi uma atividade que estava fora do meu esquema de planejamento.

Lembro também que eu trabalhei algumas coisas em grupo e era, principalmente, quando era matemática. Isso eu tinha aprendido já lá na Escola Municipal, que muitas vezes tu misturas os alunos, os fracos com os fortes, então eu fazia grupinhos, a sala de aula permitia e eu dava material concreto.

\section{MCBF: Que tipo de material?}

- BDF: Eu era, eu sempre fui muito, o meu neto sabe, a rainha da sucata, né?! Por exemplo, rolinho de papel higiênico, aquele do meio...Eu sempre fui. E como lá na Escola Municipal era uma pobreza geral, eu aprendi muito a trabalhar com materiais assim, né?! Então, ali também, na Escola, apesar de que era uma escola que tinha um mínimo de... devia ter materiais, mas eu nunca pedi material para a Escola. Então, feijão às vezes, às vezes era feijão, para... tampinha, rolhas, tudo que era coisa de contar. Fazia muita coisa de contar. Não trabalhei com blocos lógicos, naquela época eu nem sabia disso. Mas, assim... eu acho que fiz alguma coisa de geometria, não me lembro bem, mas devia ter cortado cartões e, geralmente, matemática eu gostava de trabalhar com grupos e sempre tentava misturar os grupos. Eu fiz uma coisa bem interessante, não sei se vocês já estudaram ou ouviram falar de sociodrama. Sociodrama, não sei se não tem ali. Acho que não tem ali dentro dos cadernos que emprestei pra vocês. Eu fiz um mapa assim, tu perguntas... se você fosse trabalhar em grupo, quem você gostaria de convidar? Quem é o seu preferido para trabalhar em grupo? Daí respondiam. Elas [as crianças] já sabiam escrever os nomes. Aí recolhia, isso era com os preferidos. E a outra pergunta: e com quem você não quer? Uma pessoa só que você não quer. Então aparecia. Claro que as crianças não ficaram sabendo, eu fiz um mapa, tu botas... faz várias tentativas, mas faz círculos e bota os nomes das criaturas e, daí os preferidos e os rejeitados, entende? Tu tens uma noção de como é que são as lideranças. Aparece logo, assim, quem é mais... Então, quando eu ia fazer trabalho em grupo, eu tentava ver aquilo, sem dizer pra elas, tudo criança, né, como eu misturava. Fazia isso a partir desse levantamento e, principalmente matemática, eu gostava de fazer assim. Tinha um momento, tinha muita ênfase na alfabetização, no estágio também, assim, quase que eu diria... não sei se dá para dizer isso, mas talvez a gente fosse incitado a... sendo a criança alfabetizada, vai para o segundo ano. Acho que os outros testes não eram definitivos.

Por exemplo, como foi no fim do ano para ver se sabiam ler, né, porque era um compromisso, tinha que alfabetizar. Tinha uma... sentava com uma freira, acho que era a diretora, sentava e tinha que ler. Tinha todo um tensionamento, coitada da criança, para ver se lia ou não lia, né?! Um ditado para ver, era muito assim, para ver: "bom, pode ir para o segundo ano".

Eu lembro, tinha uns... não me lembro quantos, mas uns três, acho que umas três meninas que tinham muita dificuldade, não tinham conseguido ser alfabetizadas e eu também posso ter sido incompetente, não sei, mas eu nunca vou esquecer que foi a primeira tentativa de eu ser corrompida. Porque a mãe de uma, vendo que eu já tinha entregue o boletim, a menina não tinha condições para ir adiante. Naquele tempo nem se 
pensava em alguma recuperação. Chegou dezembro e eu já tinha avisado a mãe que ela... a mãe telefonou para mim, descobriu lá um telefone do Colégio, fui chamada, fui lá, atendi, e foi muito ruim, porque eu fui vendo, eu era uma guria, eu tinha dezoito anos. Eu fui vendo na conversa dela que ela tava me propondo algum acordo, entendeu? Eu não sei se presente, ela deu a entender, assim, que a filha tinha que passar e que dependia de mim e que ela queria me conhecer melhor, que ela tinha pensado...

$\mathrm{Eu}$, depois de tudo aquilo, eu não disse nem $a$ nem $b \ldots$ A guria se reprovou, óbvio, mas eu senti depois, sabe quando [cai] a ficha, aquela mulher queria me comprar. Então, foi a primeira vez assim que eu senti aquilo, mas para mim estava tranquilo, que ela não tinha condições, e a prova final de leitura era sempre com alguém, não era só eu, né?! Tinha mais alguém ali, ali junto para decidir aprovar ou não para o segundo ano.

Basicamente, alfabetização, noções básicas de matemática e alguma coisa que a gente chamava estudos sociais, que era a família, alguma coisa assim. Primeiro ano não tinha muito que estudar história ou geografia, não era muito. Era muita leitura e escrita.

Reuniões ali no Colégio, era interessante isso, reunião de professoras, eu não lembro, não sei se porque eu era estagiária, eu não lembro de ter participado de reunião. Participava das reuniões de estágio no Colégio, mas ali, apesar de ser das mesmas freiras e tudo, eu não me lembro de nenhuma reunião. Que mais que eu poderia dizer?

Nós criamos, nossa turma foi a primeira turma que criou um uniforme pra estágio, porque a gente, já durante o Curso, a gente começou a se dar conta que, que roupa se coloca, aquela coisa de guria, né, de moça. Aí criamos, era uma saia. Inclusive os cadernos estão com um xadrezinho preto e branco, era aquele xadrezinho, só que eu é que fui atrás daquele papel, da Casa Louro ${ }^{4}$ daqui de Porto Alegre, eles tinham esse papel para embrulhar. Uma sainha justa xadrezinha e um colete. E aqui nós criamos um distintivo da Escola Normal... Então, era bom porque tu tinhas [um uniforme] certo, mudava um pouco a blusa, mas tu tinhas roupa, né, para... Tinha ali no meu momento de estágio, tinha mais, acho que mais quatro colegas da mesma escola fazendo estágio também, mas eu acho que o primeiro ano era só eu e a colega que me antecedeu.

\footnotetext{
${ }^{4}$ Loja destinada à moda feminina, muito famosa à época, localizada no centro de Porto Alegre, cujo papel para embrulho tinha fundo xadrez, em preto e branco.
}

MCBF: Tu falaste ali de alfabetização, alfabetização, de leitura, que tinha sempre alguém junto. Tu lembras como é que era isso em matemática? De avaliação, de prova.

D BDF: Eu acho que nós, pelo que eu lembro, a gente fez teste final de matemática. Não sei nem se eu guardei, posso até procurar uma provinha de matemática.

\section{MCBF: Mas, e ao longo do período de estágio?}

$\rightarrow$ BDF: Sim, eu acho que era de dois em dois meses que se tinha que dar nota, para o boletim, aí tinha um testezinho assim, mimeografado, tudo era álcool, mimeografado. Só que daí era eu mesma que decidia, a única coisa que teve uma espécie de fiscal ao lado, foi a leitura, para ver se eu não estava passando alguém que não sabia ler. Então, sentava uma por uma, acho que até num outro turno a gente ia e aí a minha criança vinha, tinha que ler alguma coisa para mim e para essa pessoa, que eu acho que era diretora.

\section{DFR: Tinha regente?}

○ BDF: Não, não tínhamos. Sabe que interessante, não tinha uma professora responsável pela minha turma, não tinha. A colega que me antecedeu, de março a julho, também não teve. Eles entregaram a turma pra nós. Isso não é comum, né?! Por exemplo, trabalhei 10 anos na UFRGS com estágios e sempre tinha que ter uma pessoa responsável e tal. Eu era a regente da turma. Não ganhava nada, óbvio, porque era o estágio, mas não tinha ninguém responsável. Confiavam em nós, não sei o que falavam para os pais. Sabe que no estágio eu não lembro, não me lembro de ter entregue boletim. Mas eu acho que eu não fiz assim, reunião com os pais. Como no município se fazia, nos sábados, vinham aquelas pessoas bem simples que a gente conversava. No estágio eu não me lembro. Falava individualmente, às vezes uma mãe me procurava, às vezes eu mandava chamar uma mãe para algum caso, mas, assim, reunião de pais eu não lembro de ter e nem reunião na Escola, de professores, eu não lembro, acho que não teve.

DFR: Você disse que ensinava para as crianças coisas de matemática. Você lembra de ter ensinado, você falou "números ou numerais de um a cem". Qual sua dúvida em relação a isso? Se você ensinava números ou numerais?

๑ BDF: Eu acho que essa palavra numeral... eu fui entender, ou construir no meu conhecimento, assim, no Curso de Pedagogia com a Léa ali. Passou a se falar em numeral, porque não, não sabia disso, falava "números". Daí, como eu estava na frente de vocês, eu disse número ou numeral [risos]. 
$\mathrm{Eu}$ ensinava números, a noção também de quantidade, mas era, assim, no primeiro ano não era muito, não se chegava... eu acho que chegava à dezena, alguma coisa de enrolar dez palitinhos e dizer, são dez palitinhos, pode-se dizer uma dezena, mas não era muito mais do que isso. A ênfase era leitura e escrita. Tu vês, hoje eu tenho convicção [de] que todo um raciocínio lógico é determinante para o resto, até, assim, a evolução em termos de leitura e escrita, ela se dá no cognitivo em geral. Então a lógica, eu acho... Eu não sei, mas acho que a contribuição da Matemática Moderna depois foi muito importante, para o próprio professor se dar conta de algumas coisas que não era para decorar, não era memorizar, era compreender, construir a noção de quantidade. Não se tinha muito isso, eu acho que a gente trabalhava, eu trabalhava com materiais concretos, mas eu acho que só depois que eu fui tendo mais, vamos dizer, clareza sobre a importância desse desenvolvimento do raciocínio. Por exemplo, não se falava, obviamente, naquele tempo ali, noção de conjunto, conjunto vazio, nada disso existia, né?! Ninguém falava nisso, isso veio um pouquinho depois, quando eu já estava trabalhando em outro lugar, trabalhando na Escola Normal, outras disciplinas.

DFR: Você lembra de mais algum conteúdo de matemática, de como você organizava, o que é que você ensinava, além desses números?

O BDF: Eu acho que dezena que eu te falei, eu lembro muito de armar a continha, isso era uma coisa bem importante, como é que armava. Que podia ser na linha horizontal ou então armar na linha vertical, isso se fazia bastante, assim. Eu acho que introduzia noção de dúzia e meia dúzia, tenho quase certeza, dúzia e meia dúzia, soma e subtração; não entravam ainda outras operações, no primeiro ano, não.

Deixa eu lembrar... Eu acho que alguma coisa de geometria, círculo, quadrado, triângulo, um pouco das noções eu acho que básicas, assim. Eu acho que era isso. Muito essa coisa de trabalhar mesmo com material concreto, somar, subtrair, depois tentar passar para o simbólico, mas bem básico. Essas contas, nunca eu acho que iam além de dez, não, não trabalhei assim soma e subtração além, eu acho que... Posso ver bem isso, não sei se os livros falam isso, se os livros, não, se os cadernos, mas eu acho que não ia, não me lembro se ia além. Acho que não.

DFR: Você disse que trabalho em grupo e matemática estavam muito relacionados, tu pedias para eles fazerem o quê, em grupo, com matemática?

- BDF: Então, tinha um pouco isso de juntar e aí fazer, por exemplo, vamos supor que eles, em um grupo eu dizia "vocês têm que fazer aqui algumas operações", usava-se esse termo operações, "podem separar", daí vamos dizer, eles lá, em grupos, sempre tinha um no grupo que pegava lá três tampinhas e duas tampinhas, "o que é que a gente vai fazer aqui?", eu tinha que passar nos grupos, "ah, 3+2. Tá, então, onde é que tem 3 e onde é que tem 2?" "Como é que a gente vai fazer agora, no papel?" Daí tinha que, cada um tinha o seu caderno, "então, vamos lá, qual é o número que vamos... qual é o número?" "três mais..." - sabiam o sinal, então, era muito isso, brincar um pouco e depois fazer no concreto e passar para o caderno as operações. "Agora vamos fazer de conta que isso aqui é uma laranja. Cada tampinha é uma laranja, alguém vai ter aqui...", eu dava muita tampinha para eles, tampinha era uma coisa que se usava muito, "alguém tem tudo isso, mas vai passar para o colega alguma coisa, como é que é?", daí eu ia lá para o outro grupo, “ah, a gente tem aqui 10 laranjas, que são as tampinhas, e aqui vai passar para o colega duas". Então era "10 menos 2", às vezes eu tinha que dizer, às vezes, quase sempre tinha alguém que dizia é 10 menos $2 \ldots$ Sempre tinha os espertinhos que eu distribuía nos grupos. "Então, tá, como é que vamos fazer isso no caderno? E se a gente quer armar essa conta, como é e tal?"

Às vezes ia para o quadro. Quadro e giz se usava muito também, era o recurso que tinha. Não tinha canetinha, não tinha. Mesmo em colégio particular, era quadro e giz e algum materialzinho. Eu me lembro, né?! minha memória também...

\section{DFR: Você lembra como é que você decidiu fazer essas coisas com matemática?}

MCBF: É eu ia perguntar também sobre isso, se na didática tinha alguma coisa...

จ BDF: Eu acho, eu acho que... Eu acho que na didática a gente... eram aulas bem ditadas, mas quando a gente teve que fazer aquele álbum que era para construir atividades, eu acho que ali tinha algumas coisas de numeração, porque eu não ia inventar isso, isso devia estar na contribuição que a Escola Normal passou. Eu não me lembro de ir lá e "ah, aqui eu aprendi isso". Aquilo ia vindo, assim, né?!

Também eu acho que a gente tinha, na época, a Revista do Ensino que, querendo ou não, sempre me auxiliou e daí, por isso que depois, ali na minha tese eu faço um capítulo sobre a Revista, porque todas as professoras também, que no caso eram professoras na escola pública do meu tempo de criança, que a Revista do Ensino tinha muitas dicas. Era uma revista que era mais procurada por causa das sugestões didáticas do que pelos textos. Só que na minha tese eu fui vendo 
que elas liam também os textos e os textos eram tudo aqui de que "não há recompensa nesse mundo...". Então, ela tinha a leitura daquelas coisas, assim, bem conservadoras, da vocação. Mas tinha muitas sugestões didáticas e a gente aproveitava também.

\section{MCBF: E as Revistas chegavam na Escola?}

O BDF: Em geral, eram professoras que tinham, mas as escolas públicas, principalmente, elas assinavam a Revista e gente dava uma espiada, né? Ou, então, alguma professora melhor de dinheiro assinava a Revista. A Revista foi um sucesso.

\section{DFR: Na Escola do estágio tinha?}

O BDF: Não lembro, eu acho que as freiras não tinham, mas eu via, não sei se nessa tia de São Leopoldo, eu tinha algumas. Eu não sei, a gente eu acho que ia atrás ou alguma colega, filha de professora... É que a partir de uma ideia se criava muito.

\section{MCBF: E na Escola do município?}

○ BDF: Não, não tinha. Mas no município tinha muito isso: das reuniões pedagógicas ali vinha muita sugestão e colegas [diziam] "olha, eu vi isso"; "olha, eu fiz aqui e tal”. Então, a gente aprendia muito com as colegas na Escola Municipal. Tem uma agora que está com mais de 80 anos, dessa mesma escola em que eu trabalhei, a gente teve um encontro em Novo Hamburgo.

\section{DFR: Você lembra de alguma atividade específica da Revista do Ensino que tenha sido marcante, mesmo que não seja de matemática?}

O BDF: Sim, eu estou tentando pensar. Eu acho que alguma coisa de geometria. Eu me lembro um pouco das figuras, assim, da ideia de que se tu vais fazer, sei lá, vai construir uma caixinha de papelão, então como é que é isso, uma caixinha aberta, uma caixinha fechada. Um pouco isso é que eu lembro, acho que alguma coisa por aí. E o que mais, o que me vem, assim, na memória, são figuras, que a Revista trazia e daí dava sugestões. Eventualmente, eu acho que, porque, a gente na época não chamava histórias matemáticas, mas tinha o que a gente chamava "o problema", então na medida em que as crianças iam aprendendo a ler, a gente já começava a colocar alguma coisinha "resolva"... "o fulaninho tinha nananana... quanto ficou?" Então já tinha pequenos, não sei como é que se chama isso, que depois mais tarde começaram a dizer que... chamar de "histórias matemáticas". Mas era, assim, pra resolver a partir de um texto.

O que tinha muito ali no tempo do estágio, havia essa, como é o nome? Não sei de onde que veio essa tendência de globalização, tu estás falando num assunto, daí tu tentas colocar matemática dentro desse assunto, vamos supor que tu estivesses falando sobre o dia da árvore, lá em setembro, aí fazia uma unidadezinha sobre a primavera e daí os assuntos da matemática tentava, chamava "globalizar". Isso depois virou piada, porque diziam que nas frações esquartejavam até o Tiradentes lá [risos] e virou muita piada, como é que tinha aqui no Instituto de Educação Flores da Cunha? Falavam que alguém tinha que... porque aí tu davas um nome para o que se chamava uma unidade de ensino para trabalhar quinze dias com aquilo e daí alguém disse que, acho que era no quarto ano que eles trabalhavam com o Rio Grande do Sul, que alguém deu o nome de "Multiplicando pelas Coxilhas" [risos], queria globalizar o Rio Grande do Sul com multiplicação, sabe.

Saiu muita piada que em geometria colocava o lençol da dona Leopoldina [risos] e aí tinha que fazer não sei... calcular a área, mas não duvido, porque era muito forte essa coisa assim "mas como é que eu vou fazer, se eu vou falar lá sobre o dia da bandeira, então eu vou dar umas coisinhas de matemática que é duas bandeiras mais cinco bandeiras, vamos desenhar...", porque eu estou falando do dia da bandeira, entende? Isso aí era muito [comum] na época, [se] chamava globalização. Aí a leitura também tinha que tratar do assunto, sempre tinha um foco. Mas, às vezes, era bem forçado o foco, não digo que fosse uma exigência, mas era uma coisa que valorizavam muito.

\section{DFR: Você falou dos programas... Você os comprou?}

○ BDF: Não, não, eu acho que não estavam todos à venda. Hoje eu fico pensando, mas como é que numa livraria tinha isso? Porque era um material, acho que da editora Tabajara, nós tínhamos umas editoras em Porto Alegre, Tabajara ou Selbach, era uma coisa assim. E alguém me disse que tinha lá na tal livraria Flores e eu fui comprar. Eu devo ter comprado de português e matemática, eu não sei que fim levou, que eu acho que vale a pena vocês olharem, porque aquilo me ajudou muito, né?! Porque tinha um certo roteiro, tinha uma lógica ali. E que vinha, do que se chama Centro de Pesquisa e Orientação Educacionais (CPOE), eles é que elaboravam isso e davam uma orientação para todo o Rio Grande do Sul. E no tempo das provas prontas, um dos capítulos lá da minha tese, as provas prontas se baseavam muito nesses programas, então o professor sabia que daquilo ali ia sair uma prova que a Secretaria ia mandar para todas as escolas no fim do ano. Então nesse sentido era para ter uma unidade.

\section{MCBF: Inclusive para o primeiro ano?}

- BDF: Sim, todo mundo tinha. Claro que cada um dentro do seu nível. Tenho que achar esses programas. 
Parece que eu estou vendo na minha frente. Porque era uma coisa que se abria assim, sabe? Ele era dobrado. Então aquilo chama muito a atenção, mas acho que é porque tinha... era na horizontal.

Mas daí eu estava tentando me lembrar se era o conteúdo e sugestões de atividades, mas não sei porque é que tinha... porque assim eram os conteúdos, mas aqui tinha eu acho que exercícios, isso eu já não me lembro, mas isso aí durou bastante tempo.

DFR: Você mencionou as provas de final de ano e que vinham provas prontas. $O$ que é que você lembra disso no seu estágio?

○ BDF: Então, o que é mais interessante é que essas provas não passavam nem pela escola particular, que meu estágio foi numa escola de freiras, e nem na municipal, que era a outra experiência que eu tinha na época, então eu, eu não vivi as provas prontas. Não me lembro de ninguém falar das tais provas. Nos colégios privados a gente tinha sabatina, tinha provas, mas não havia uma coisa "ah, vamos ver aquelas provas", eu ouvia falar de quem estudava no grupo escolar, por exemplo, mas eu não. E como professora também não passou por mim.

Era só nas escolas estaduais. Era assim uma lei de todo o estado, e que teve críticas, que muita gente sofreu com isso, mas teve também elogios, porque era um período [em] que o CPOE tinha muito claro uma visão científica, então tudo era avaliado, tudo era quantificado, trabalhavam com estatísticas, tinham relatórios maravilhosos, então as provas faziam parte deste modelo científico de educação.

DRF: A regulação da escola particular, você lembra como é que se dava, quem é que definia?

จ BDF: Eu só lembro disso, que vinham inspetoras do sistema estadual e que elas ficavam por lá, na sala da diretora. Às vezes a diretora ou as freiras diziam "olha, visita da inspetora; olha, ela vem para a sala de aula", a inspetora entrava, dava bom dia, mas não fazia perguntas. Eu imagino que as freiras eram super organizadas, que elas faziam o que devia ser feito, entendeu? Eu me lembrei agora, que eu falei para vocês que eu fui lá no Colégio para procurar, eu queria na verdade ver, eu queria saber se lá no Colégio Santa Catarina, se lá teria documentação da época. Nesse livro, aqui é um livro para diplomação, caderno, olha o que está escrito ali ó..."Beatriz Terezinha Daudt, filha de José Luis e Sibila, natural de Hamburgo Velho, Rio Grande do Sul. Nascida em 30 de janeiro de 1948, concluiu o Curso Normal, Normal Colegial, em conformidade com as leis vigentes pelo que lhe é conferido o presente diploma de professor Primário.
Novo Hamburgo em 6 de dezembro de 67, assinado...". Aí vinham as assinaturas.

MCBF: Beatriz Terezinha, diplomada, Nadir Teixeira Morais era a inspetora.

O BDF: Ela vinha da SEC para inspecionar o Colégio, devia ter outros colégios.

MCBF: Mas esse documento aí está no Colégio?

O BDF: Está no Colégio. Tem um livrão assim. E tem desde quando o Colégio foi fundado assim, tem de todo mundo, que eu imagino que a inspetora tinha que, principalmente a inspetora, tinha que assinar.

DFR: Você falou da equipe de supervisão, como é que se compunha essa equipe?

○ BDF: Então, tinha as freiras e tinha professoras leigas.

MCBF: $\mathrm{E}$ as professoras leigas eram...?

O BDF: As professoras leigas, até hoje que eu sei dos colégios que tem estágio, é geralmente alguém que ganhava por essas horas de supervisão, além das outras, era um professor, todas elas professoras que foram nossas professoras, entende.

\section{DFR: Elas eram do Curso Normal?}

จ BDF: Do Curso Normal. Elas não eram estranhas. Então, por exemplo, no meu tempo ali do estágio tinha a Irmã Carmem, que era das artes, ela visitava, ela tinha feito trabalhos de educação artística, porque a gente fazia muita coisa para as crianças. Tinha outra freira que dava aula, sim, de matemática. Acho que tinha umas sete supervisoras de estágio, nós éramos uma turma de quase quarenta, devia ter 20 num semestre e 20 no outro semestre, mais ou menos.

Eu gostava de estudar, a minha família não é uma família que tem estudos assim, da família, eu era a que mais gostava de estudar, tanto que o meu irmão não estudou. O sonho do meu pai era que o meu irmão estudasse e não eu, para que mulher estudar? Entende? Ainda era essa mentalidade. Só que eu é que gostava de estudar, então eu sempre fui boa aluna, me dava superbem com os professores, líder de classe. Isso facilitava um pouco, estudiosa, né?! Isso facilitava um pouco, eu ir bem no estágio também, eu acho que eu tinha, sei lá, as competências básicas e tal. E me dava bem com os professores, até porque eu acho que eu fazia um bom trabalho também. Então eu não tive, como algumas colegas tiveram, crise no estágio, teve uma que quase desistiu, [chegou a se] incompatibilizar com a equipe supervisora e tal.

$\mathrm{Eu}$ acho assim que essa equipe de supervisão, eu fico imaginando se elas se reuniam para comentar, 
elas tinham que se reunir para comentar como é que estão indo as estagiárias, quem é que precisa de mais orientação. Eu fico imaginando que algumas colegas de estágio deviam ter dificuldades, ou não faziam como deviam fazer, e aí eu acho que elas se reuniam para comentar sobre a gente.

$\mathrm{Eu}$ soube no dia, na noite da formatura, as notas finais e aí eu e uma outra colega soubemos, a freira veio dizer que nós duas tiramos o primeiro lugar no estágio. Mas não era 100, era 99. Não era 9,9, era 99, e daí que eu soube. Eu achava que eu tinha ido muito bem, pelo que elas diziam, às vezes conversavam, por exemplo, elas ficavam lá no fundo da sala, geralmente, às vezes davam uma caminhada entre as crianças e às vezes saíam. Às vezes elas saíam, iam para o recreio, que chamavam o intervalo, aí conversavam um pouquinho. Eu via que elas diziam coisas positivas para mim, eu vi que eu estava indo muito bem. Mas não era assim uma informação direta "olha, parabéns, tu estás indo muito bem", a não ser essa que me disse "olha, irmã fulana disse que gostaria de ser tua aluna, porque está encantada com o que tu estás fazendo".

Eu era muito criativa, a sala de aula era bonita, eu levei peixe num aquário quando eu quis introduzir a letra $\mathrm{X}$ e aí toda uma história e como é que íamos alimentar o peixe. Daí já trabalhava globalizado, entendeu? Por que é que o peixe pode ficar dentro da água, o que é que ele tem, vamos ver como é que o peixe respira. Isso ia tudo junto assim, né?

Realmente, sempre gostei de ser professora. Mas tinha colegas que tiveram, sim, dificuldades. A ponto de uma, eu não sei se uma, acho que uma se reprovou até no estágio. Porque ela não apareceu na formatura, eu acho que ela... Mas também isso não ficava muito, que até era bom né, não ficava muito claro assim.

\section{DFR: Como era a rotina das inspetoras durante o estágio? \\ จ BDF: Bom, primeiro eu disse que a gente nunca sabia} quando elas viriam. E elas andavam pelas escolas, eu acredito, eu acho que devia ser assim. [Por exemplo], Fulana é uma professora que dá aula para a Escola Normal, mas uma vez por semana ou duas ela tem horas para visitar essas escolas de estágio. Eu imagino que era assim. E eu penso, também, pelo que eu soube das colegas, que algumas colegas recebiam mais visitas que outras, talvez para verificar se estavam... até imagino que elas deviam às vezes chamar algumas, dizer "olha como tu estás fazendo, tu estás equivocada". Eu sei, porque depois eu fui supervisora na UFRGS por 10 anos acompanhei a equipe de estágio. Eu acho, pelo que as gurias falavam, as minhas colegas, que não era tanto orientação, era mais cobrança. Isso me passou essa ideia assim, sabe.

MCBF: E no teu caso, elas entravam na sala?

$\rightarrow$ BDF: É elas falavam muito pouco assim, mas, sim, entravam.

\section{MCBF: Ficavam?}

○ BDF: Ficavam, ficavam um tempo, eu não sei quanto tempo elas ficavam. Claro que a gente sempre se preocupava um pouquinho, né?! Geralmente se sentavam no fundo da sala ou davam uma olhada nos cadernos das crianças, depois davam um tchau, alguma coisa assim, às vezes conversavam um pouquinho. Mas não vinha muito comentário não, e nos cadernos tinha isso de visto.

\section{MCBF: Era naquela hora que elas faziam o visto?}

๑ BDF: É que eu tinha dois tipos de caderno, um caderno que era mais "o que é que eu vou fazer amanhã". E um "do que é que eu fiz". Chegava o amanhã, aí eu tinha que escrever o que é que fiz, não fiz, né?! Em geral eram esses, esses dois eram básicos, e um que era o comprovante. O que é que era o comprovante? Cada dia uma criança escrevia, então tudo que se fazia, por exemplo, no quadro, alguma atividade, aparecia nesse caderno comprovante, que eu acho que eu te dei junto, né?! E, claro, eu sempre pensava assim, quanta coisa eu faço e não está no caderno, porque naquele tempo... hoje eu fotografaria, porque atividades que o aluno não ia escrever, sei lá, vamos dizer que eu planejasse uma aula que ia ter música, isso tinha pouco, mas tinha, uma canção que eu ia ensinar alguma coisa, dia dos pais, muita coisa não ia para o caderno, mas daí lá no caderno comprovante do aluno... Esse que cada dia era um aluno que escrevia, isso era lei, tinha que ter. Isso tinha no município também. Cada dia um aluno escrevia, aquele caderno era o "comprovante", ou seja, o que é que foi feito em aula. Só que o que não aparecia escrito, mas tinha feito, tinha que aparecer um registrozinho no meu caderno chamado "diário", que eu planejei e que eu executei e tal.

Agora eu fico pensando, eu fico muito curiosa, isso que eu queria ver no Colégio, mas ela disse que não tem, uma reunião delas comentando sobre o estágio, sabe. Quando eu fui lá, eu tinha muita vontade de ver isso, eu nem sei se faziam ata mesmo, talvez até para se assegurar que ninguém soubesse, eu não sei, mas isso eu não consegui. E também nunca conversei...

DFR: Então, para a gente encerrar, o que é que você aprendeu de mais marcante nesse estágio?

O BDF: Eu tinha, antes eu tenho que dizer isso, eu tinha um certo receio [de] que, porque eu ia entrar no 
segundo semestre com criança, e criança fica muito fixada na professora, então eu tinha receio que ia ter uma certa comparação com a que me antecedeu. Não aconteceu, acho que ela preparou, ela foi muito legal, ela preparou bem as crianças e os pais também, eu acho, não sei. Então isso era uma preocupação, essa coisa não teve. Eu acho que o que mais assim ficou para mim é que, bom, eu posso ser professora, eu sou uma boa professora, para mim ficou muito claro, pelos pequenos elogios que eventualmente vinham ou de alguma mãe, de uma ou outra supervisora de estágio, e sabiam que os alunos gostavam muito de mim.

Nas reuniões, eu percebia isso nas reuniões, que daí estavam todas, as que estavam estagiando e a equipe, alguns exemplos que elas davam "olha o que poderia fazer", eram coisas que eu tinha feito. Foi bem legal, elas não diziam "olha, a Beatriz fez". Mas eu, então pensava assim, eu estou no caminho certo, entende. Me deu muito isso, assim, que bom, eu sou uma boa professora! Isso era importante pra mim, porque isso é um desafio. Lá no município eu já estava de Março até Julho, mas é diferente, né?! Primeiro que lá as crianças [eram] super pobres, os pais não tinham nenhuma exigência da gente, então se eu não fizesse alguma coisa, talvez nem notariam. A diretora era muito boa, e tinha todo esse grupo, então eu já achava que lá eu estava indo bem. Tanto que no fim do ano, na Escola Municipal, a diretora me chamou e disse "eu quero que ano que vem tu assumas uma turma que esse ano a professora $x$ não conseguiu", as crianças todas não aprenderam a ler. Então ela queria que eu fizesse tipo de um primeiro e segundo ano... Foi a turma mais pobre que eu tive. Tanto que quando eu fiz um trabalho, eu já te falei isso, de ir atrás dos meus primeiros alunos, fiz um artigo sobre isso. E aquela turma, que era a turma mais pobre, eu não consegui um. Não sei onde estão. Porque os outros, era aquela coisa, um indica o outro. Daquela turma eu não consegui nenhum e, não sei...

Era uma turma muito pobre e eu peguei aí... foi um desafio para mim, ou seja, também a diretora na Escola Municipal tinha acreditado no meu trabalho, entende? Então, eu acho que eu fiquei, assim, revigorada e daí eu escolhi ser professora, que era o que eu mais queria e estou me dando bem. Acho que foi isso que eu me lembro.

MCBF: Por último, tu falaste dessas reuniões, já que vocês todos estavam em estágio, né? Em que horário acontecia isso?

จ BDF: Sim, olha, nós tínhamos reuniões em sábados de tarde. Porque as escolas (de estágio e outras) trabalhavam muito em sábados de manhã naquela época. E várias reuniões de estágio foram sábados de tarde lá no Colégio Santa Catarina. Acho que todas, não sei se não foram todas em sábado de tarde. Era bom, porque daí a gente se encontrava, porque a turma que se encontrava todos os dias quando era aluna, agora no estágio a gente só se encontrava com as que estavam estagiando na mesma escola. Então também para nós, colegas de turma, era uma festa se encontrar nas reuniões.

\section{MCBF: Eram só as que estavam estagiando naquele semestre?}

D BDF: Só as que estavam estagiando. Me parece que daí, [para] a última reunião do ano elas chamaram as outras, porque daí já tinha que preparar a formatura.

\section{MCBF: Então, no primeiro semestre tu não participaste de nenhuma reunião?}

๑ BDF: Não. Não participei de nenhuma reunião. Eu sabia o que uma estagiária que é uma muito amiga minha me contava, porque ela era estagiária no primeiro semestre. Ela pegou no São Luiz uma turma de terceiro ano. E ela me contava algumas coisas, assim. Mas não sabia mais nada não.

Se vocês lembrarem de outras coisas...

[Agradecimentos e encerramento da entrevista].

Recebido em: 31/3/2019.

Aprovado em: 23/5/2019.

Publicado em: 8/11/2019.

Endereço para correspondência:

Diogo Franco Rios

Av. Juscelino Kubitschek de Oliveira, 2200

Bloco 26-B, ap. 204 - São Gonçalo

96075-810, Pelotas, RS, Brasil

\section{Autores:}

Diogo Franco Rios

Doutor em Ensino, Filosofia e História das Ciências pela Universidade Federal da Bahia/Universidade Estadual de Feira de Santana (UFBA/UEFS), 2012.

Orcid: https://orcid.org/0000-0001-8391-5721

E-mail: riosdf@hotmail.com

Maria Cecilia Bueno Fischer

Doutora em Educação pela Universidade do Vale do Rio dos Sinos (UNISINOS), 2004

Orcid: http://orcid.org/0000-0002-0537-4111

E-mail: mceciliabfischer@gmail.com 